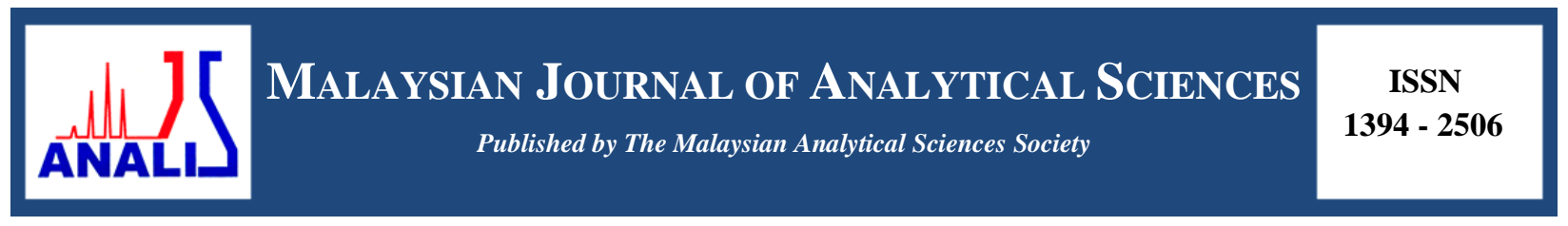

\title{
PROTON EXCHANGE MEMBRANE FUEL CELL/SUPERCAPASITOR HYBRID POWER MANAGEMENT SYSTEM FOR A GOLF CART
}

\section{(Sistem Pengurusan Kuasa Hibrid Sel Bahan Api Membran Penukaran Proton/Superkapasitor untuk Kereta Golf)}

\author{
Siti Afiqah Abd. Hamid ${ }^{1}$, Ros Emilia Rosli ${ }^{1}$, Edy Herianto Majlan ${ }^{1}$, Wan Ramli Wan Daud ${ }^{1}$, Ramizi Mohamed ${ }^{2}$, \\ Teuku Husaini ${ }^{1}$, Ramli Sitanggang ${ }^{3}$ \\ ${ }^{I}$ Fuel Cell Institute \\ ${ }^{2}$ Department of Electrical and System Engineering, Faculty of Engineering \& Built Environment, \\ Universiti Kebangsaan Malaysia, 43600 UKM Bangi, Selangor, Malaysia \\ ${ }^{3}$ Department of Chemical Engineering, Faculty of Industrial Engineering, \\ Universitas Pembangunan Nasional “Veteran” Yogyakarta, Yogyakarta 55283, Indonesia \\ *Corresponding author: edy@ukm.edu.my
}

Received: 5 February 2016; Accepted: 22 April 2016

\begin{abstract}
This paper presented the transformation of a golf cart system powered lead acid battery into an environmental friendly hybrid vehicle. The design developed by using an advantage contributes by the uprising alternative power source candidate which is Proton Exchange Membrane Fuel Cell (PEMFC) and the maintenance free energy storage device, a supercapacitor (SC). The fuel cell (FC) stack was an in house manufactured with $450 \mathrm{~W}(36 \mathrm{~V}, 12.5 \mathrm{~A})$ power, while the SC was from Maxwell Technologies $(48 \mathrm{~V}, 165 \mathrm{~F})$. This two power sources were controlled by the mechanical relay, meanwhile the reactant (hydrogen) are control by mass flow controller (MFC) both signaled by a National Instrument (NI) devices. The power management controller are programmed in the LabVIEW environment and then downloaded to the NI devices. The experimental result of the power trend was compared before and after the transformation with the same route to validate the effectiveness of the proposed power management strategy. The power management successfully controls the power sharing between power sources and satisfies the load transient. While the reactant control managed to vary the hydrogen mass flow rate feed according to the load demand in vehicular applications.
\end{abstract}

Keywords: proton exchange membrane fuel cell, supercapacitor, hybrid, power management strategy

\begin{abstract}
Abstrak
Kertas kerja ini membentangkan tentang transformasi sistem kereta golf dikuasakan oleh bateri asid plumbum kepada kenderaan hibrid yang mesra alam. Reka bentuk ini dibangunkan dengan menggunakan kelebihan yang disumbangkan oleh sumber kuasa alternatif iaitu Sel Bahan Api Membran Penukaran Proton (PEMFC) bersama peranti penyimpanan tenaga tanpa penyelenggaraan, Superkapasitor (SC). Tindanan Sel Bahan Api (FC) telah dibina sendiri dengan kuasa $450 \mathrm{~W}$ (36 V, 12.5A) manakala SC adalah dari Teknologi Maxwell (48V, 165F). Kedua-dua sumber kuasa ini dikawal menggunakan geganti mekanikal, sementara itu bahan tindak balas (hidrogen) dikawal menggunakan meter pengawal aliran (MFC) yang kedua-dua diisyaratkan dengan menggunakan peranti Instrumen Nasional (NI). Pengawal pengurusan kuasa diprogramkan di dalam persekitaran LabVIEW dan kemudiannya dimuat turun kepada peranti NI. Hasil eksperimen trend kuasa telah dibandingkan sebelum dan selepas transformasi dengan laluan yang sama untuk mengesahkan keberkesanan strategi pengurusan tenaga yang dicadangkan. Pengurusan kuasa ini berjaya mengawal perkongsian kuasa di antara sumber kuasa dan memenuhi kehendak beban fana. Manakala kawalan bahan tindak balas berjaya mengurus kadar aliran hidrogen mengikut permintaan beban dalam aplikasi kenderaan.
\end{abstract}




\section{Siti Afiqah et al: PROTON EXCHANGE MEMBRANE FUEL CELL/SUPERCAPASITOR HYBRID POWER MANAGEMENT SYSTEM FOR A GOLF CART}

Kata kunci: sel bahan api membran penukaran proton, superkapasitor, hibrid, strategi pengurusan kuasa

\section{Introduction}

Today, with increasing number of vehicles on the road that used internal combustion engine (ICE), concerns about the inability to supply sufficient fossil fuels is increasing because the failure to discover new oil sites and the impact of pollution produced are more serious [1]. As a consequence, much interest in new solutions to replace ICEs powered vehicles has increased steadily [2].

Nowadays the hybrid system technology becoming new phenomena in transportation area. These technologies are developed to help reduce the pollution made by ICEs vehicles. The interest in the hybrid vehicle has open new aspects to optimize its performance. The component of hybrid power sources are such as petrol, diesel engines, electric motor/generator units, batteries (BTs), SCs and FCs. The first commercial hybrid vehicle was introduced by Toyota in 1997 named Prius, and many more coming to the market from other vehicle manufactured throughout the world such as Honda, Hyundai, Lexus, BMW, Mercedes-Benz and many more. This type of vehicle used BT as the auxiliary source. However, BT has its own limitation. When the life time of BT depend on the reactant material and electrodes. Moreover, once energy stored is depleted, the BT needs to be recharged and if the performance degrades, the BT will be replaced with new ones. So, using BT produce wastage that involve time and cost.

Currently, the world is seeking for a more reliable power source where FC as an alternative energy is one of the best candidates. This technology offer variety of advantages over existing power sources and based on its specific characteristics where the reactants source is not limited, efficient energy, light in weight, fuel flexibility, and ability to provide power to the range of diverse applications [3-5]. FC technology generates power through an electrochemical reaction between hydrogen and oxygen. The process emitting zero pollutants gases, greenhouse gases, and hazardous waste make it an environmentally friendly, quiet and considered a green energy source of power generator [6,7]. There are various types of FCs, one of it is Proton Exchange Membrane Fuel Cell (PEMFC). This type of FC is the most popular choice and highly sought after development of this technology in recent years. It is much more compatible towards vehicle, portable and stationary applications. This is evidenced by some of the world's great enterprises were using or developing this technologies such as Horizon Fuel Cell, Ballard Power Systems, Power Energy, Daimler-Chrysler, General Motors, Honda, Toyota and many more.

Many interest to build a FC car since it is a green car with zero pollutants as the result of an electrochemical process in FC that produces electric with only water and heat as byproduct compared to conventional ICE automobiles that emit carbon dioxide and volatile organic compounds that do not burn. However, FC is known to have a slow dynamic response to load changes that many have agreed FCs alone might not be sufficient to satisfy the load demands in vehicular applications [8-11]. The slow dynamic response of FC will lead to more serious problem like permanent cell damage, system stall, or reduced the cell lifetime. This is due to fast load demand that cause fuel starvation where it happen when a high voltage is drop in a short time. The hybridization of FC with energy storage devices that is SC or also known as Ultracapacitor (UC) are claim much helpful by the researchers where it minimize the size of this power generator and increase it efficiency by storing the regenerative braking energy from the vehicle [7, 11-19]. SCs are well known with it characteristic of fast charge and fast discharge without damaging its structure. SC also have more life cycle compare to BT, thus less wastage.

However, due to it fast discharge characteristic, this device need to combine with power generator (such as ICE or FC) before it can apply to vehicle. This combination (hybrid) SCs and FCs are being examine by several researchers with various control strategy to support FCs [9, 12, 16, 20, 21]. Eren et al. [21] studied fuzzy logic based supervisory controller of FC/UC hybrid for vehicular power system. Lin and Weng [16] studied the adaptive optimal-control method of a FC/UC hybrid power system. While Ates et al. [12] studied the energy management based on combined neural network-wavelet transform of FC/UC hybrid for vehicular application. Thounthong et al. studied the energy management based on differential flatness control of FC/SC hybrid sources [17] and a DC link voltage regulation FC/SCs hybrid power sources for vehicular application. Erdinc et al. [22] studied the waveletfuzzy logic based load sharing and control algorithm of FC/UC hybrid for vehicular application. In contrary to the 
other positive results achieved in the literature of PEMFC with SC/UC vehicles hybridization, reference in [14, 19] claims that this combination are rarely used because of the high power train cost.

Another characteristic of FC are the current produced fluctuate due to the change in load and input reactants [23, 24]. Reviews from various studies indicate that the performance of PEMFC is very dependent on the conditions of operation, in which the voltage generation depending on the dependent variable to be controlled. Among the important factors for power generation from the FC is design of balance of plant (BOP). BOP works to supply the right amount of power to the right place and at the time required. BOP can improve the electrochemical reaction in PEMFC and ensure operational stability even in times of uncertainty interrupt its capability. Therefore, it will improve the performance and durability of PEMFC $[25,26]$. The BOP often built in PEMFC based on humidity system, water management, operating temperature, pressure and the appropriate flow rate response [27-33]. Every parameter plays their own role where the design will determine the correct amount need to be supply function to result in better generation of electricity. Here, the focus is the reactant mass flow rates where the hydrogen amount to be supply are the biggest concern for power generation. The fuel management is design with the controller to prevent the occurrence of unsatisfactory fuel supply that will limit the ability of FC to deliver the power being request from load.

With nearby growing era of FCs in transportation sector, it is very important to understand this technology in its applications. In this paper, development, manufacturing and car assembly of the PEMFC as a power generator are done with hybridization with SC as the secondary power supply. To avoid the high cost and complex control system, golf cart are used as a prototype FC car using DC $3 \mathrm{~kW}$ electric motor. The power management of this hybrid FC car and reactant control system are done using LabVIEW program and applied using NI devices.

\section{Fabrication of PEMFC stack}

\section{Materials and Methods}

Two stacks with 40 cells each built consists of end plates, current collectors, bipolar plates, gas diffusion layer, membrane electrode assemblies (MEA), and sealants that are sandwiched together. Bipolar plates used instead of single plates in this stack to reduce the FC size. The flow fields are engraved using a computer numerical control (CNC) machine. The stacks built are connected in series to obtain higher voltage value. Flow field pattern and size of the bipolar plate (anode and cathode) are designed and produce an output power of $450 \mathrm{~W}$ at $36 \mathrm{VDC}$. The PEMFC stack is designed based on the FC open cathode system with air as cooling system. For the anode side, the flow shape build with the serpentine flow but for cathode, straight flow are engraved. The size of both plate are 30 $\mathrm{cm}$ length and $11 \mathrm{~cm}$ width, with the plate area $330 \mathrm{~cm}^{2}$. The material of bipolar plate is a mixture of graphite and carbon materials.

The MEA as the heart of FC consists of three main components namely gas diffusion layer (GDL), membrane and catalyst layer. The performance of FC is much depends on the good electrode and electrolyte (MEA) composition and research to improve the performance of both materials are necessary for the successful manufacturing process. A fabrication, characterization and performance tests of nano catalyst platinum-ruthenium-nickel/carbon (Pt-Ru$\mathrm{Ni} / \mathrm{C}$ ) done to improve the performance of MEA. Nano materials are potential for increasing performance of FC through the nano impact. Production of $\mathrm{Pt}-\mathrm{Ru}-\mathrm{Ni} / \mathrm{C}$ catalyst in this research is expected to increase carbon monoxide (CO) tolerance caused by the oxidation of $\mathrm{CO}$ or low $\mathrm{CO}$ adsorption process. Developments are focus on the design and manipulation of materials structures at the atomic or molecular level to provide a more effective catalyst. This composite can be used to overcome problems such as high production costs, corrosion and CO poisoning of the electrode, thus can improve the durability, stability and performance of the FC. For electrode, the anode and cathode electrodes used carbon fiber paper as gas absorption distribution layer and catalyst platinum/carbon $(\mathrm{Pt} / \mathrm{C})$ as an electrochemical reaction layer. GDL are made from carbon paper, while for the membrane, Nafion ${ }^{\mathrm{TM}}$ being used as a proton exchange membrane. Method of manufacturing GDL and catalyst layer are by spraying method. The main ingredient of catalyst is Pt/C with $0.3 \mathrm{mg} \mathrm{cm}^{-2}$. The three components are pressed at $350^{\circ} \mathrm{C}$ for three minutes before merge to become MEA. The thickness of each MEA produced was around 0.23 $\mathrm{mm}$. Figure 1 shows the PEMFC stack built. 


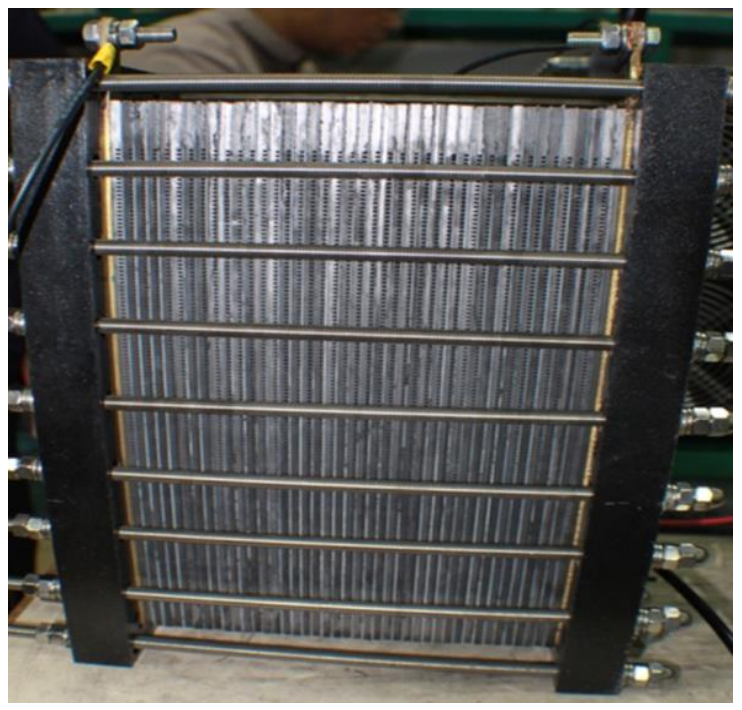

Figure 1. Fabrication of single stack open cathode PEMFC

\section{Balance of plant (BOP)}

The PEMFC performance relies mainly on the design and operation of a FC system that includes the BOP and power converters as well as their control systems. The complexity of the FC requires many studies on the design and operation of these units. This PEMFC system used pure hydrogen that stored in cylindrical pressurized tank with $7.2 \mathrm{~m}^{3}$ capacity flowed in FC stack with pressure control using a pressure regulator. The hydrogen flow are using continuous mode, but it supplied based on request load. The reactant control system build [34] are used to ensure the gases entering the stack is sufficient with the amount of power produced. Otherwise for oxygen in cathode sides, fans are used to blow source of oxygen from the air. Eight fans powered with $24 \mathrm{~V}, 0.5 \mathrm{~A}$ each is used and the fan speed applied at the maximum rate to ensure the air flow is sufficient for the reaction at the cathode as well as to cool the stack. The flow diagram of reactant controller is shown in Figure 2.

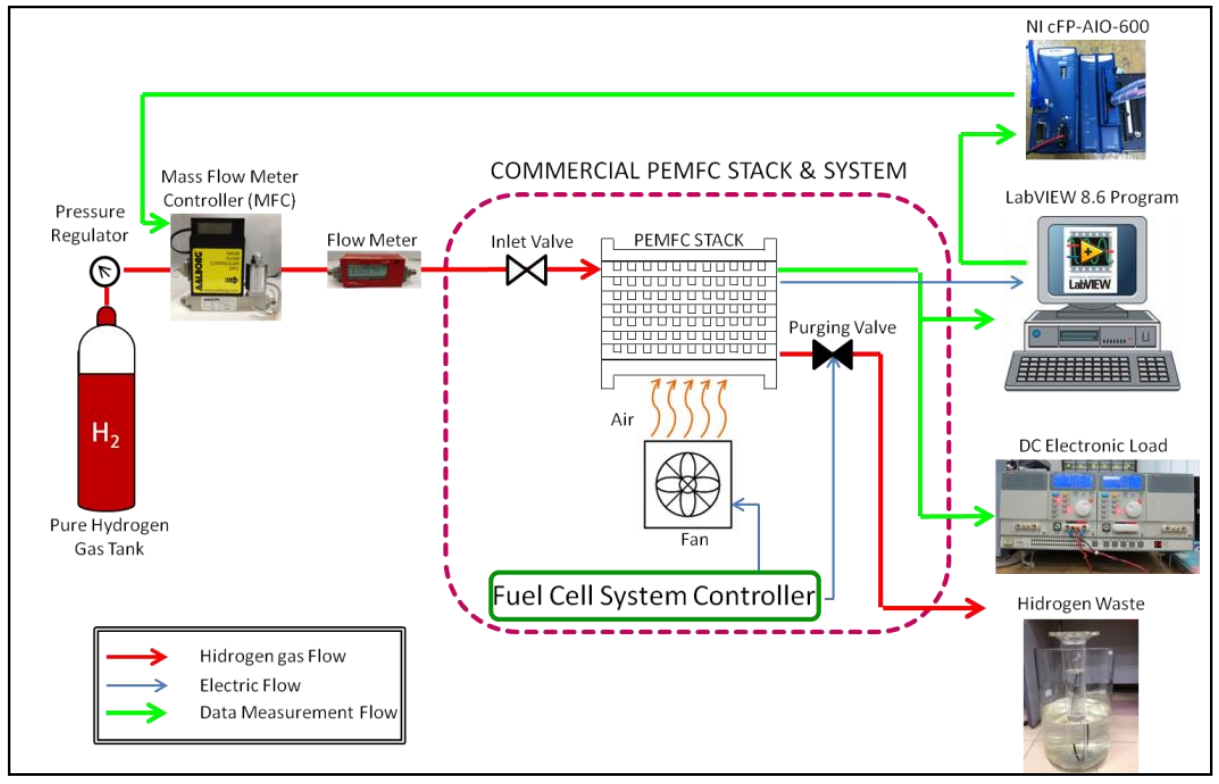

Figure 2. Flow diagram reactant controller of PEMFC stack 
NI-cFP-AIO-600 is one of standard products from NI that provides precise data acquisition. It used in this experiment to measure and monitor the input voltage, current, power and to control the gas flow via the output current. It consists of four analog voltage or current input channels with 11 input ranges up to $\pm 36 \mathrm{~V}$ or $\pm 24 \mathrm{~mA}$ and four analog current output channels ranging from 0 to 20 or 4 to $20 \mathrm{~mA}$ without over-ranging. The NI module placed between FC system and a computer (LabVIEW) to convert the analog input to a digital output for the cFP measurements and controlling actions. Voltage ranges to maintain suitable flow rates was determined. This voltage measured and the signal logged using the NI analog input (NI-cFP-AIO-600 - voltage input-channel 1) and sent to LabVIEW controller program to be processed. The required flow rate will automatically choose using the PID program. The signal then sent back using the NI analog output current (NI-cFP-AIO-600 - current output-channel 3) to control the MFC valve flow rate. The program react are based on the PID changes that can produce an operating signal that manipulates the flow rate of the hydrogen reactant to maintain stack output voltage. The PID controller program developed as shown in the front panel on Figure 3 and the detail of the structure is shown in the block diagram in Figure 4.

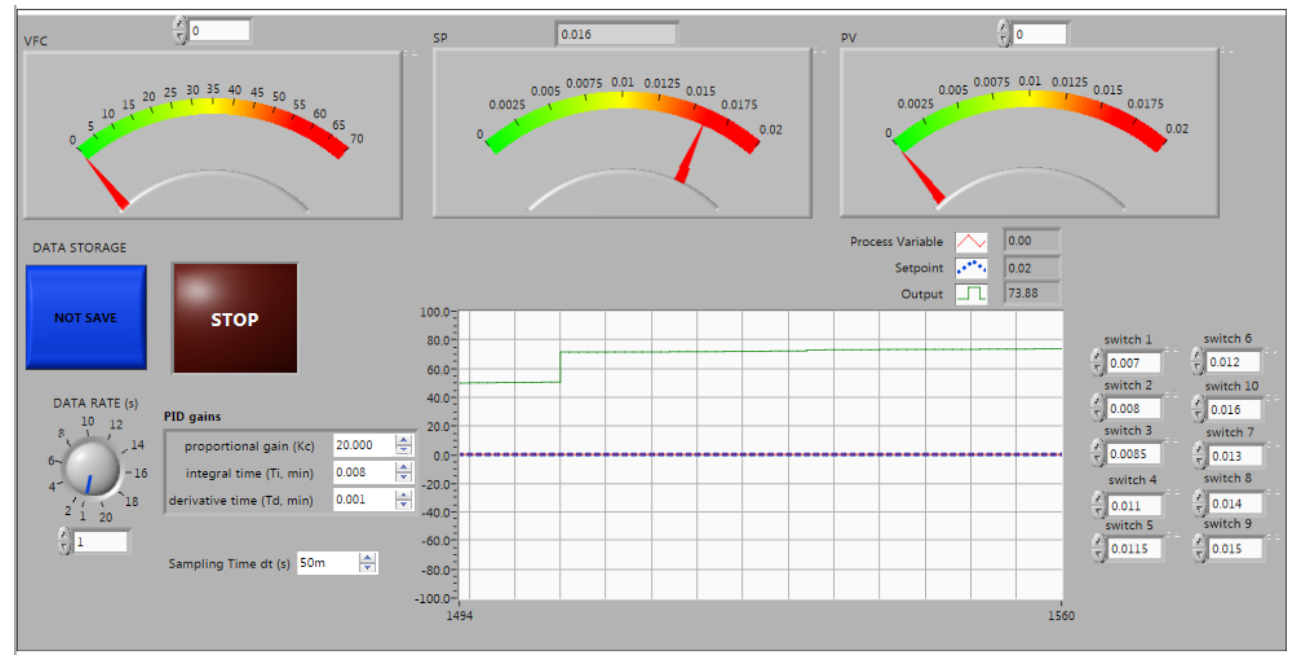

Figure 3. Front panel interface of PID control system for reactant control

\section{Golf Cart specification after transformation}

A golf cart serves as the vehicle prototype. Originally, the BTs used in the golf cart as the power generator, then it was replaced with FC and SC. The space required are to place the hydrogen storage tanks, FC stack, SC, and power management system. Figure 5 showed the modification done to the golf cart during this study. Power management system unit is designed for $3 \mathrm{~kW}$ power to control the golf cart motor. This unit are integrated with a FC system that control the amount of hydrogen into the FC stack conducted in accordance with the power requirements. The Global Positioning System (GPS) and collection or storage of data is designed and installed in this prototype car using seagull devices, NI devices and LabVIEW program. 
Siti Afiqah et al: PROTON EXCHANGE MEMBRANE FUEL CELL/SUPERCAPASITOR HYBRID POWER MANAGEMENT SYSTEM FOR A GOLF CART

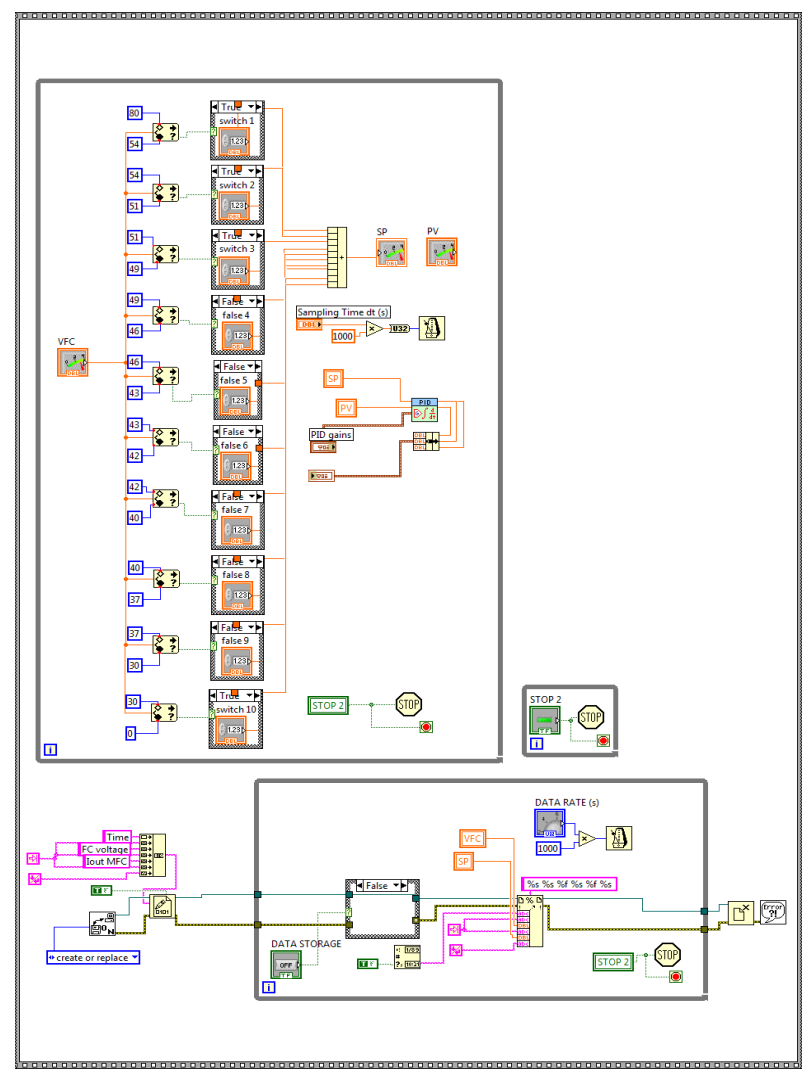

Figure 4. Block diagram interface of PID control system for reactant control

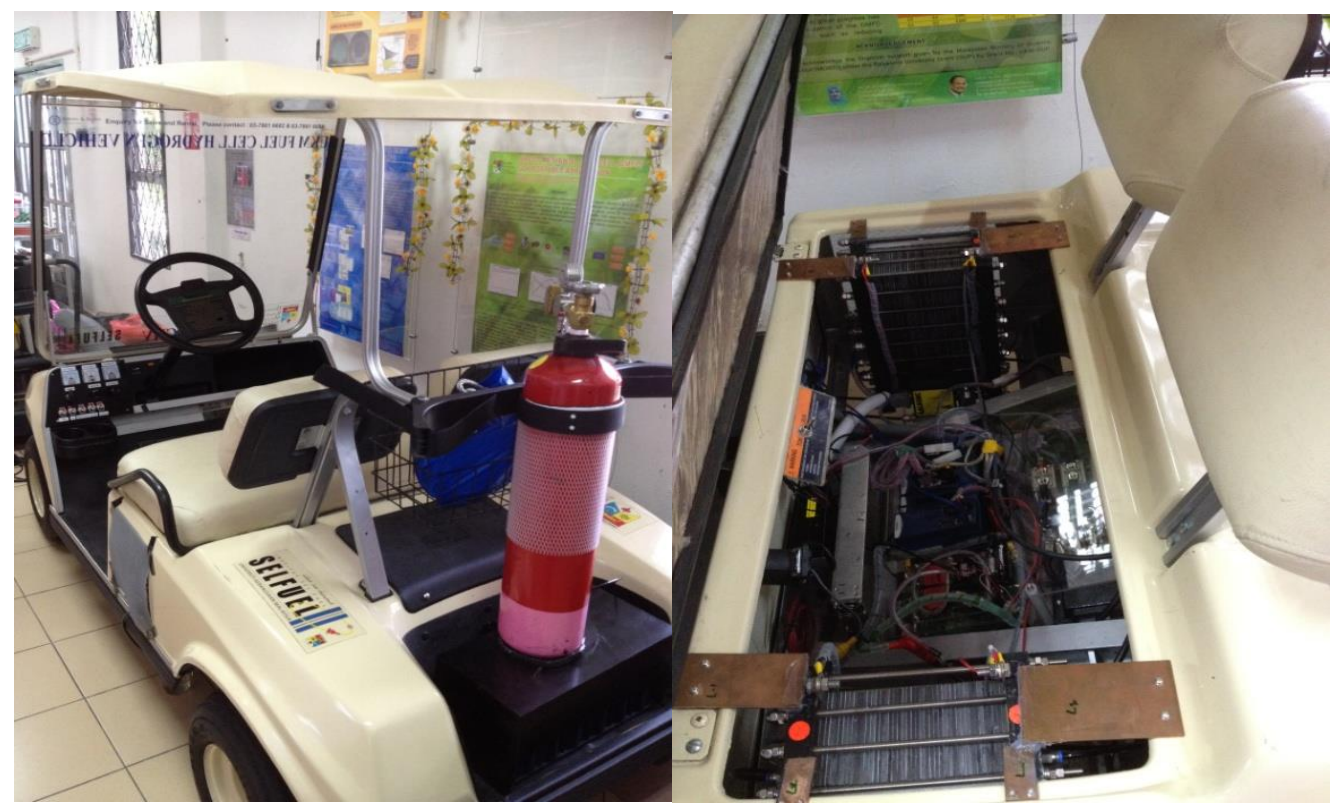

Figure 5. Prototype golf cart after modification 
The SC model BMOD0165 from Maxwell Technologies used as the auxiliary power source in this hybrid system are with a rated voltage of $48 \mathrm{~V}$ and rated capacitance of $165 \mathrm{~F}$. Its features are compact, rugged, fully enclosed splash proof design was the main points that make this SC the primary choice. The benefit of choosing SC rather than BTs was because it provide over 1,000,000 duty cycles which is a thousand times more than average BTs.

All components built are assembled and tested on a golf cart, and the system was constructed and equipped with manual and automatic hydrogen flow valve functions. The manual function was prepared as a safety precaution to avoid severe circumstances that could occur during testing, and also used as the start-up function for the electronic components in the cart. After all required electronic parts are functioning, the valve switch to automatic valve to control the hidrogen mass flow rate during speed changing or load demand, and changes in the stack voltage reading will vary the hydrogen flow rate according to the programmed control structure. The flow diagram for hydrogen is displayed in Figure 6.

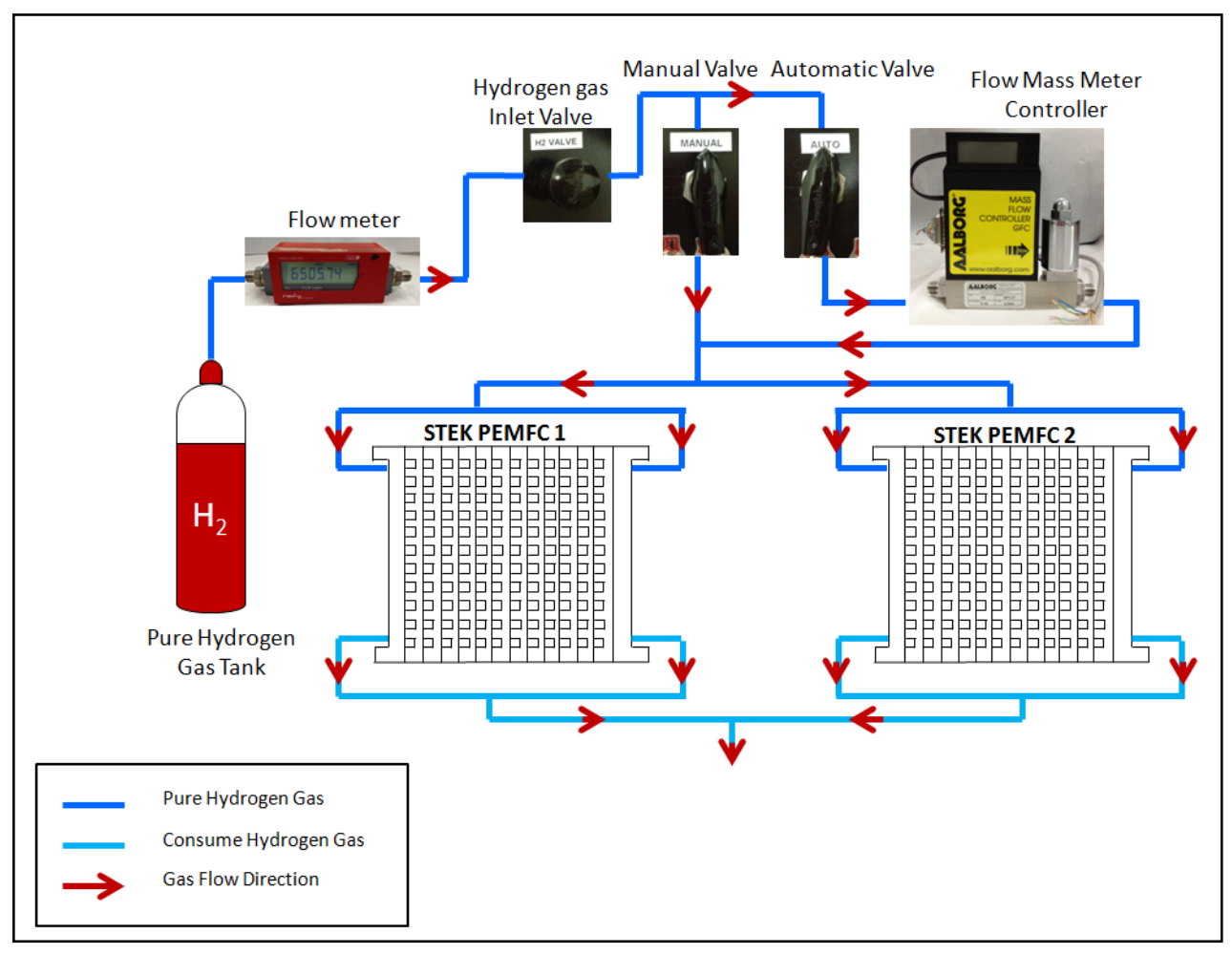

Figure 6. The flow diagram of hydrogen on a golf cart

\section{Power management strategies of hybrid vehicle}

The hybrid system combines the FC and the SC to run the golf cart. The FC in this system serves as the primary power source to satisfy the load and to charge the SC. In contrast, the SC acts as the auxiliary power source to supply any load amount that exceeds the capability of the FC. This power management system contains two components, one of which is the controller circuit unit and the other is the power controller device. These two components are related to one another through the controller circuit, which carries out the power management strategy programmed in the power controller device.

The focuses of this study are design and developed the controller circuit unit. This unit includes power relays, recovery diodes, and a DC/DC converter. This system uses the power relay as a switch to allow power flow for discharging or charging the SC. The power relay required a supply of $12 \mathrm{~V}$ voltage and $417 \mathrm{~mA}$ current to function. 


\section{Siti Afiqah et al: PROTON EXCHANGE MEMBRANE FUEL CELL/SUPERCAPASITOR HYBRID POWER MANAGEMENT SYSTEM FOR A GOLF CART}

The relay chosen was model G9EA1B from OMRON, which is capable of allowing a 100 A maximum switching current suitable for the golf cart system. The recovery diode is a 150UR series from International Rectifier and functions as a blocking device to ensure that the current flows only in one direction, as directed by the diode. The objective is to decide when to charge and when to discharge the SC as programmed in the controller. The DC/DC converter is a voltage stabilizer device. As the load demand increase, the FC output voltage will decrease. This phenomenon is well understood as a characteristic of FC technologies, but application devices will not tolerate this situation because they require a stable operating voltage within a certain tolerance. The golf cart must be supplied with $48 \mathrm{~V}$, which is also the output voltage of DC/DC converter used in this system and the input voltage for converter are from FC.

The power management strategy is programmed in the LabVIEW software that will be integrated with the cFP device. In this application, extensive palette of functions and tools connected by strings are used to meet the strategy objective. The block diagram of the power management strategy are shown in Figure 7. The power management strategy used in the golf cart is based on voltage regulation, and the control strategy is described below:

1) If the load voltage is greater than $48 \mathrm{~V}$ and the $\mathrm{SC}$ voltage is greater than or equal to $48 \mathrm{~V}$, the excess power from the FC will be supplied directly to the motor.

2) If the load voltage is greater than $48 \mathrm{~V}$ and the $\mathrm{SC}$ voltage is less than $48 \mathrm{~V}$, the excess FC power will charge the SC.

3) If the load voltage is less than $48 \mathrm{~V}$, the SC will discharge to meet the load power demand.

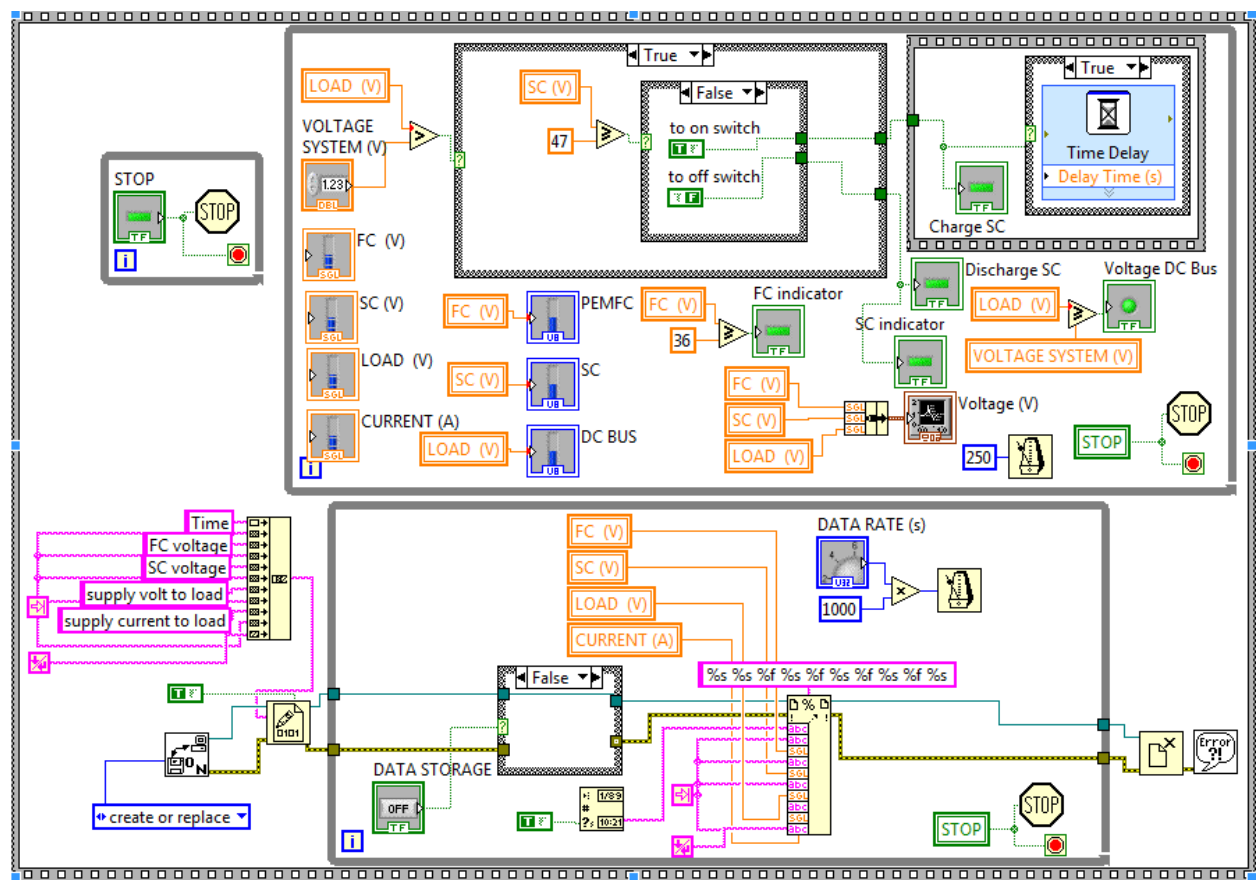

Figure 7. Block diagram of power management program

\section{Results and Discussion}

Performance test of the prototype FC hybrid cars done in and outside the laboratory. FC system performance testing in the laboratory will use the FC system performance test. For test outside the laboratory, prototype FC cars are designed and manufactured with equipment to be able to record and store the data needed for doing performance test. 


\section{Electric golf cart - before transformation}

The performance test of the golf cart before transformation was done on a route around UKM in the Figure 8 . The test was done to check the performance of the golf cart with BT system. The speed, current drawn from BT, voltage of the system and the resultant power of the golf cart are recorded during the route. This result (Figure 9) was a benchmark to compare with the new hybrid system proposed. The golf cart power requirement and the capability of golf cart are discovering during this test. The highest altitude the golf cart climb was around $110 \mathrm{~m}$ above sea level, the maximum speed of the golf cart can be move by this motor are around $20 \mathrm{~km} / \mathrm{h}$ throughout the test. The highest current draws are $77.13 \mathrm{~A}$ during climbing up slopes. The voltage are fluctuates from $44 \mathrm{~V}$ to $54 \mathrm{~V}$ maximum due to discharge and charge of BTs during the course, but the average voltage of $48 \mathrm{~V}$ are required to run the golf car motor that being set by the motor controller. The power consumption extract from this test was not more than $4 \mathrm{~kW}$.

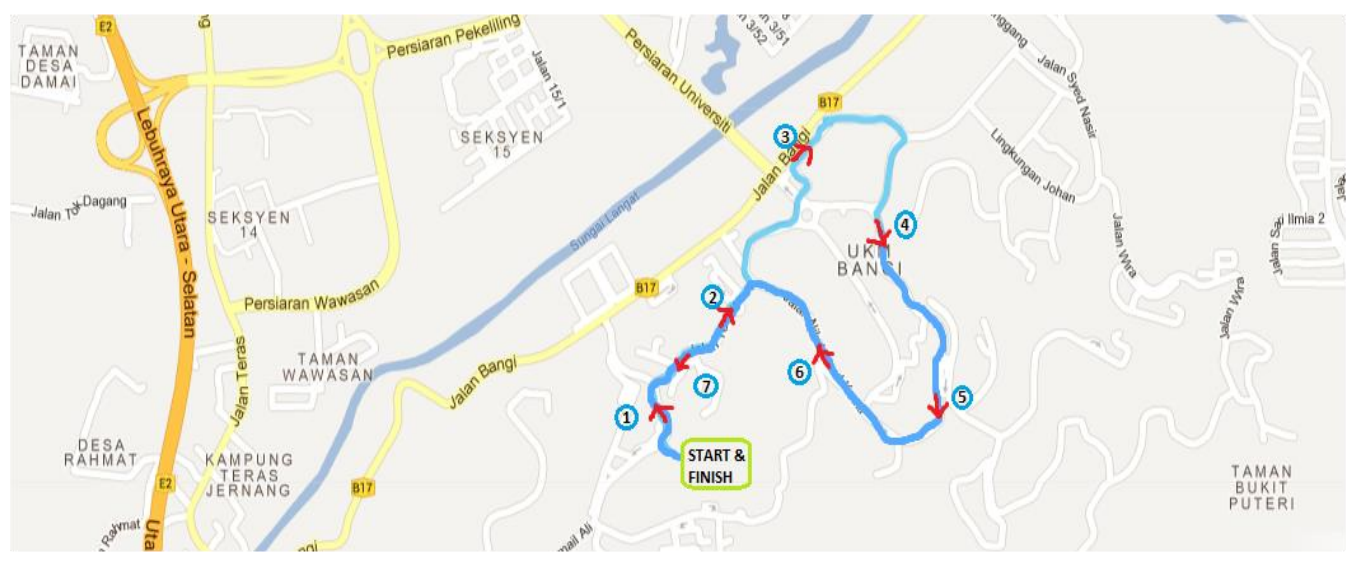

Figure 8. Route map of on road test

\section{Hybrid golf cart - after transformation In laboratory testing}

The development of the reactant system was applied towards the stack as in Figure 2 and the system was tested in the laboratory using electronic load 3311D to change the value of the load variations. Test results are shown in the Figure 10 where the polarization curve plotted shows that the highest amount of power can be drawn from the FC stack is around $380 \mathrm{~W}$. The flow rate of hydrogen change with the increasing load in Figure 11, this prove that controlling of hydrogen flow rate amount are essential in order to supply sufficient reactant amount to have a good power performance. In Figure 12, the graph show the voltage fluctuation as the test done resultant form the LabVIEW program measurement, the setpoint current programmed function well as the voltage change to satisfy the current output getting from the controller. 
Siti Afiqah et al: PROTON EXCHANGE MEMBRANE FUEL CELL/SUPERCAPASITOR HYBRID POWER MANAGEMENT SYSTEM FOR A GOLF CART

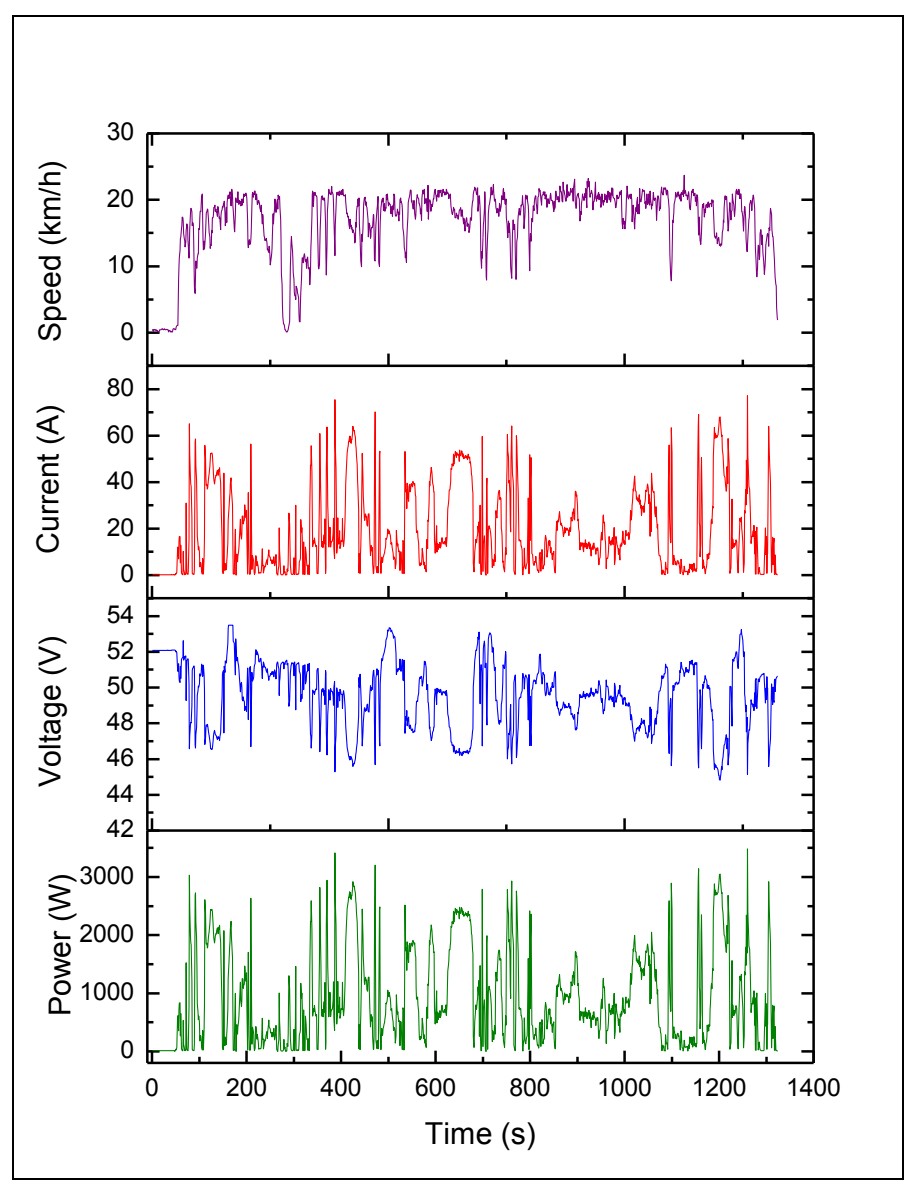

Figure 9. Measurement of speed, current, voltage and power response during on road testing using BT as power generator

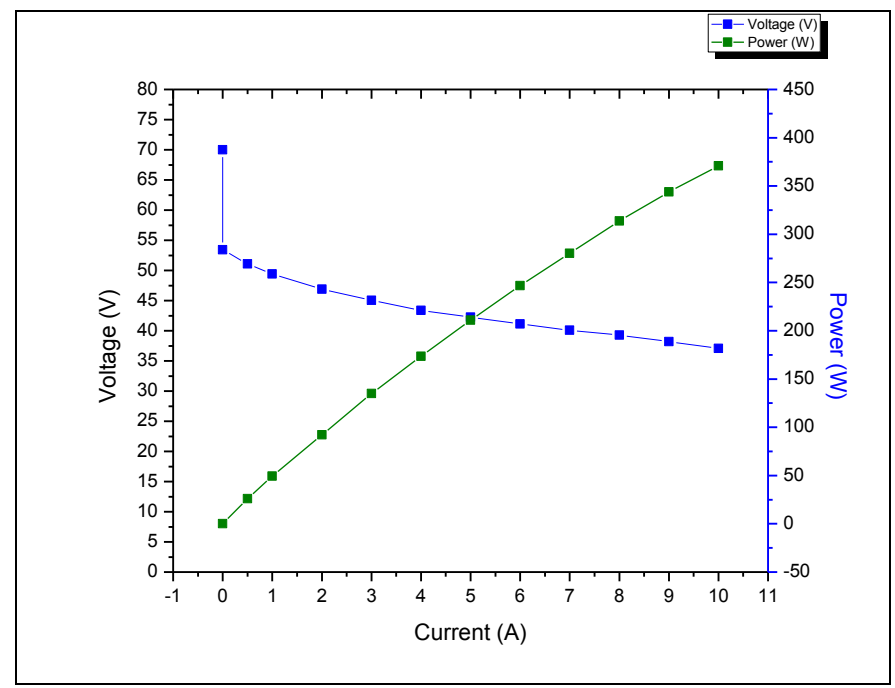

Figure 10. Polarization curve of power and voltage changes on the current towards fabricate FC stack 


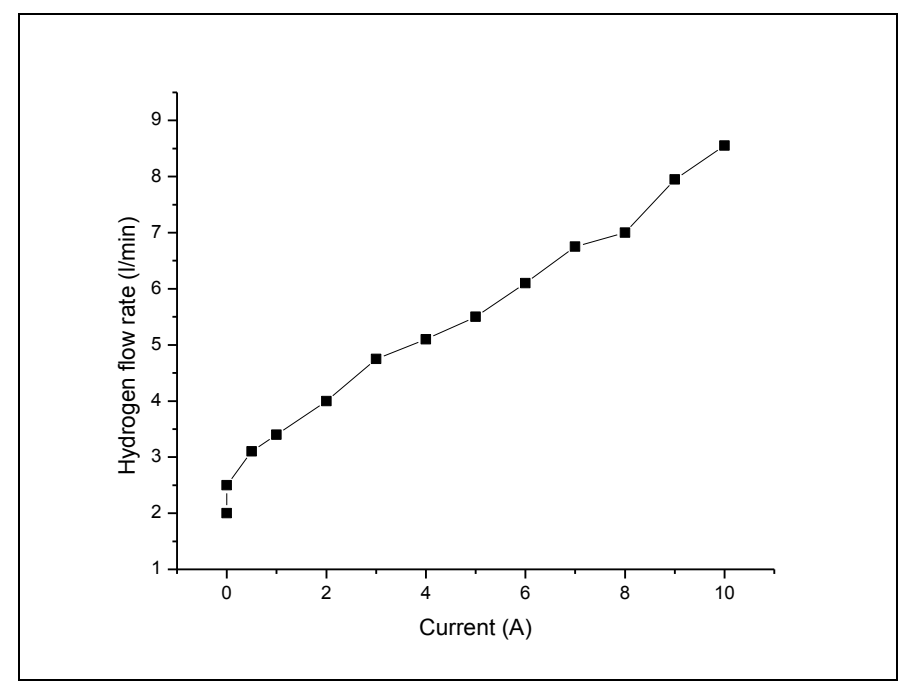

Figure 11. Hydrogen gas flow rate changes with variation of load

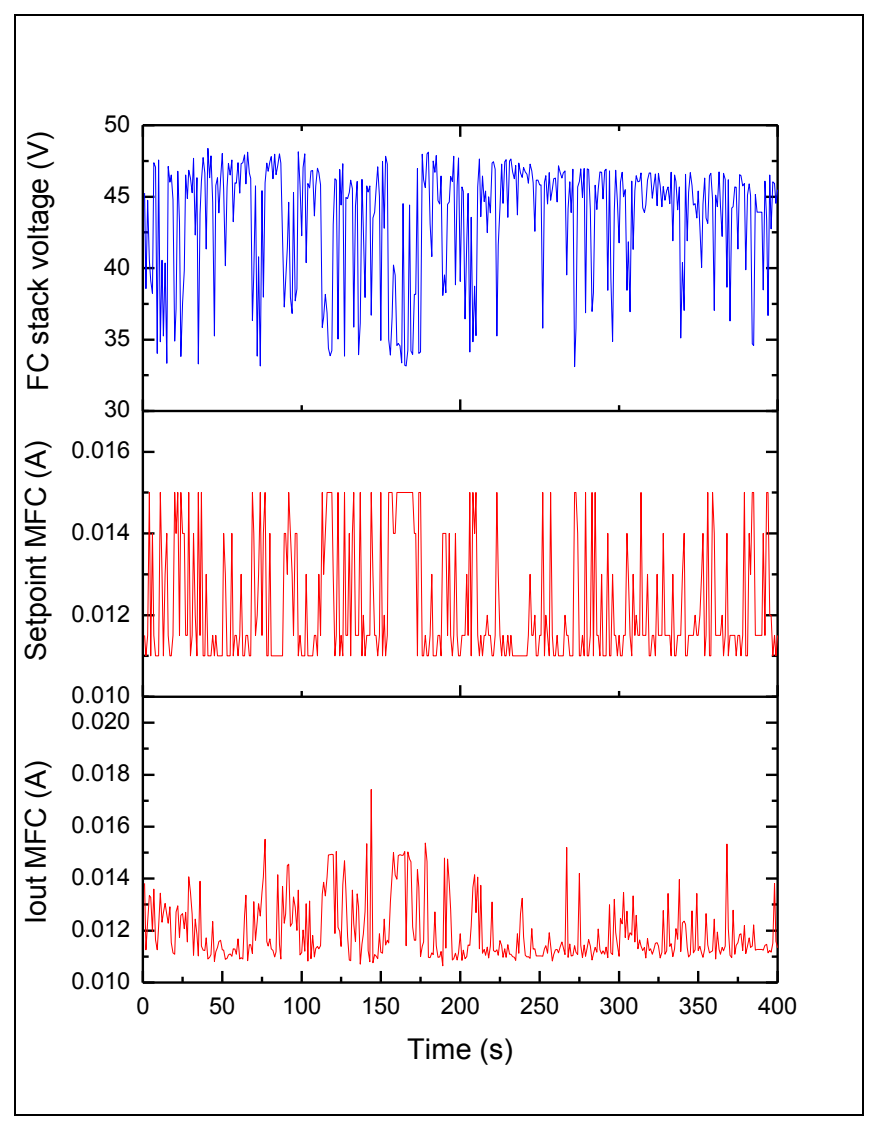

Figure 12. Measurement of voltage variation with change response of current setpoint andoutput form mass flow controller 


\section{On road testing}

For on road tests, the reactant control system built was applied to the FC stack, and FC are as the primary source and the power management system used to control the FC stack and SC for golf cart to replace the six pieces of $8 \mathrm{~V}$ lead-acid BTs connected in series before. The on road tests after transformation are done with the same route before. The test objective was to make sure the hybrid system work and the power management system flow are working as they are programmed. This new power management system was working as programmed but due to existence of slope in the route, the SC discharge rapidly and worst depleted. The speeds are maintaining not more than $15 \mathrm{~km} / \mathrm{h}$ so it can sustain throughout the test. The new hybrid golf car was worked successfully with the power sources helping each other to serve the load demand. Due to reduce in weight of golf cart as described in Table 1, the current consumption drawn also reduced. Their average currents are $17 \mathrm{~A}$. The resultant powers are also decrease and there are not fluctuate so much as before. The results are shown as in Figure 13.

Table 1. Weight and volume comparison of the transformation of the FC/SC hybrid system with the BT system

\begin{tabular}{llcc}
\hline & & BT & FC/SC hybrid \\
\hline BT (6 unit) & Weight $(\mathrm{kg})$ & 174 & - \\
& Volume $\left(\mathrm{m}^{3}\right)$ & 0.0809 & - \\
FC (2 stack) & Weight $(\mathrm{kg})$ & - & 26 \\
& Volume $\left(\mathrm{m}^{3}\right)$ & - & 0.0441 \\
$\mathrm{SC}$ & Weight $(\mathrm{kg})$ & - & 14.2 \\
& Volume $\left(\mathrm{m}^{3}\right)$ & - & 0.0152 \\
Total & Weight $(\mathrm{kg})$ & 174 & 40.2 \\
& Volume $\left(\mathrm{m}^{3}\right)$ & 0.0809 & 0.0593 \\
\hline
\end{tabular}

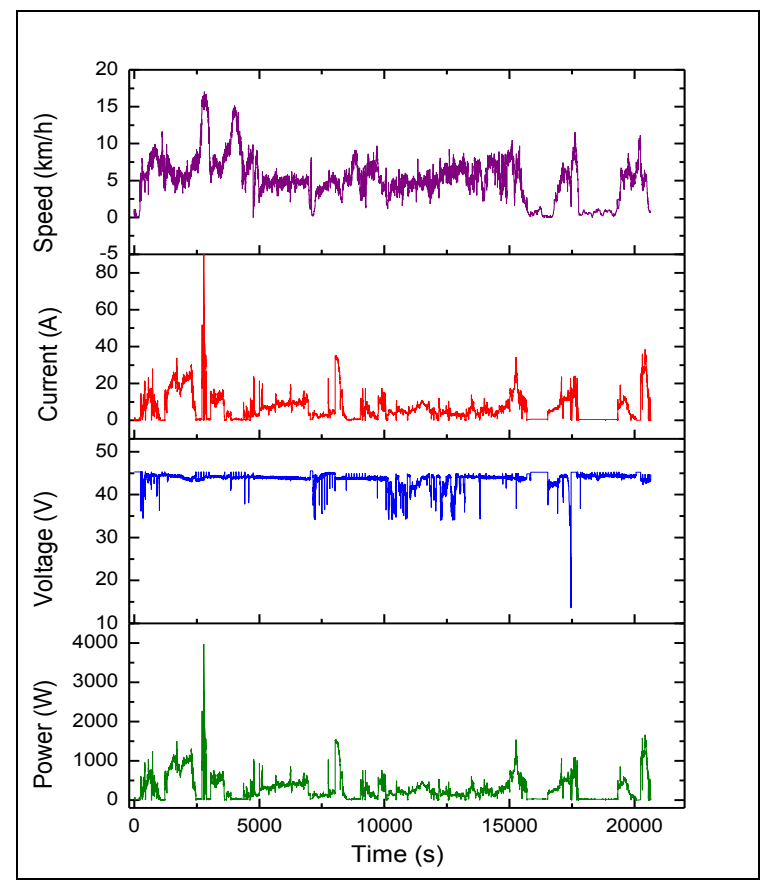

Figure 13. Measurement of speed, current, voltage and power response during on road testing using FC and SC as power generator 
From Figure 14, the voltages of the golf cart power source are shown. The FC stacks are successfully maintaining the operating voltage with the help from DC/DC converter. As we can see from the second graph, SC voltage begin to depleted at $700 \mathrm{~s}$. FC voltage from $700 \mathrm{~s}$ onward fluctuations rapidly as it try to charge the SC. The SC voltage begins to increase at $1500 \mathrm{~s}$ and the FC voltage fluctuation reduces a bit. The graph proves that the power management is working as the strategyprogram in LabVIEW. Moreover, the last graph shows the resultant voltage from FC and SC. A SC can advance the load, following the characteristics of the main sources by providing a stronger power response to the changes in system load. During essential steps in the load, the SC provides the energy balance needed during load transition periods. Adding energy storage (SC) to the power generator (FC) systems improves power quality and efficiency. The graphs clearly proof the function of having SC as the auxiliary power source.

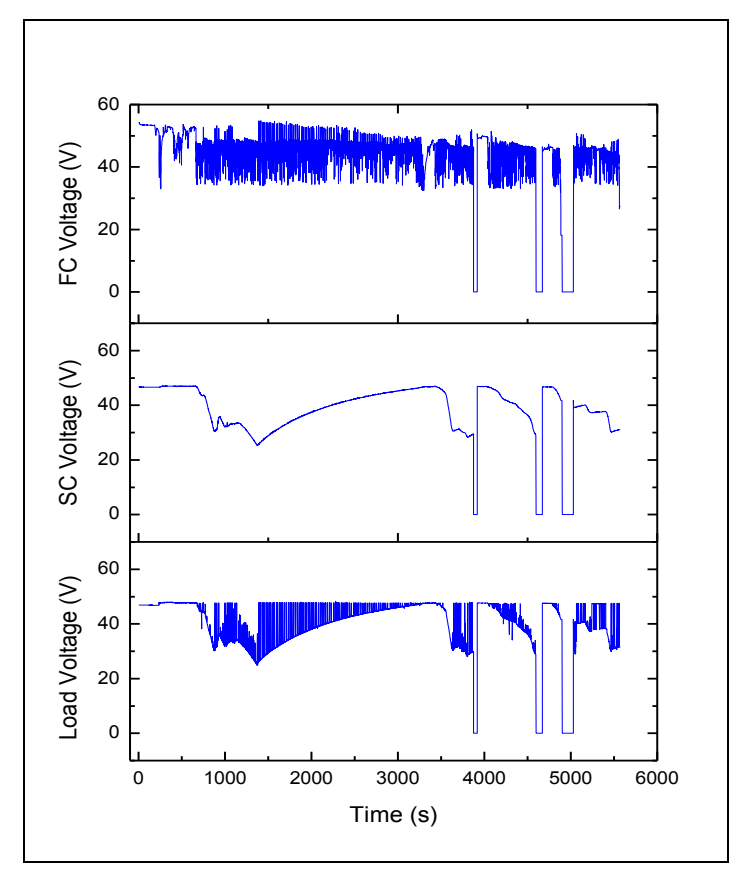

Figure 14. Measurement of FC, SC and load voltage

\section{Conclusion}

The transformation of the commercialize electric golf cart powered by the conventional lead acid BT done by replacing the power generator to more environment friendly power source that is PEMFC and SC. This hybrid vehicle development includes from the PEMFC manufacturing process, to the reactant controller of the FC stack, as well as the hybrid power management controller. The PEMFC build consist of two stacks connected in series to add up their equivalent voltage to be sufficient with the motor. The reactant controller is focus on the flow rate of the hydrogen supply to adjust with the requested load power in order to meet the reaction requirement and reduce from excess waste to atmosphere. The power management controller manages the power flow of the FC and SC to meet the load demand. The controller program work successfully and satisfy the required load and the use of PEMFC and SC in hybrid vehicle appear to be environmentally benign and sustainable option to overcome the environment pollution made by ICE vehicles.

\section{Acknowledgement}

The authors gratefully acknowledge their thanks to Universiti Kebangsaan Malaysia for their financial support provided through a University Research Grants; UKM-AP-TK-08-2010, DIP-2012-05 and AP-2013-010. 


\section{References}

1. Chen, B. (2009). Ultracapacitor boosted fuel cell hybrid vehicle, elecrical engineering. Thesis Msc: pp. 130.

2. Erdinc, O., Vural, B. and Uzunoglu M. (2009). A wavelet-fuzzy logic based energy management strategy for a fuel cell/battery/ultra-capacitor hybrid vehicular power system. Journal of Power Sources, 194(1): 369 - 380.

3. El-Sharkh, M.Y., Rahman, A. and Alam, M.S. (2004). Neural networks-based control of active and reactive power of a stand-alone PEM fuel cell power plant. Journal of Power Sources, 135(1-2): 88 - 94.

4. Thanapalan, K. K. T., Williams, J. G., Liu, G. P., and Rees, D. (2008). Modelling of a PEM fuel cell system. Proceeding of the 17th World Congress - The International Federation of Automatic Control, Seoul, Korea.

5. Shen, M., Meuleman, W. and Scott K. (2003). The characteristics of power generation of static state fuel cells. Journal of Power Sources, 115(2): 203 - 209.

6. Shen, M. and Scott, K. (2005). Power loss and its effect on fuel cell performance. Journal of Power Sources, 148: $24-31$.

7. Uzunoglu, M. and Alam, M. S. (2007). Dynamic modeling, design and simulation of a PEM fuel cell/ultracapacitor hybrid system for vehicular applications. Energy Conversion and Management, 48(5): 1544 - 1553.

8. Jeong, K. S., Lee, W. Y. and Kim, C. S. (2005). Energy management strategies of a fuel cell/battery hybrid system using fuzzy logics. Journal of Power Sources, 145(2): 319 - 326.

9. Thounthong, P., Raël, S. and Davat, B. (2006). Control strategy of fuel cell/supercapacitors hybrid power sources for electric vehicle. Journal of Power Sources, 158(1): 806 - 814.

10. Bernard, J., Hofer, M., Hannesen, U., Toth, A., Tsukada, A., Büchi, F. N. and Dietrich, P. (2011). Fuel cell/battery passive hybrid power source for electric powertrains. Journal of Power Sources, 196(14): 5867 5872.

11. Erdinc, O. and Uzunoglu, M. (2010). Recent trends in PEM fuel cell-powered hybrid systems: Investigation of application areas, design architectures and energy management approaches. Renewable and Sustainable Energy Reviews, 14(9): $2874-2884$.

12. Ates, Y., Erdinc, O., Uzunoglu, M. and Vural, B. (2010). Energy management of an FC/UC hybrid vehicular power system using a combined neural network-wavelet transform based strategy. International Journal of Hydrogen Energy, 35(2): $774-783$.

13. Caux, S., Hankache, W., Fadel, M. and Hissel, D. (2010). On-line fuzzy energy management for hybrid fuel cell systems. International Journal of Hydrogen Energy. 35(5): 2134 - 2143.

14. Fernandez, L. M., Garcia, P., Garcia, C. A. and Jurado, F. (2011). Hybrid electric system based on fuel cell and battery and integrating a single $\mathrm{dc} / \mathrm{dc}$ converter for a tramway. Energy Conversion and Management, 52(5): $2183-2192$.

15. Khaligh, A. and Zhihao, L. (2010). Battery, ultracapacitor, fuel cell, and hybrid energy storage systems for electric, hybrid electric, fuel cell, and plug-in hybrid electric vehicles: state of the art. IEEE Transactions on Vehicular Technology, 59(6): 2806 - 2814.

16. Lin, W.S. and Zheng, C.H. (2011). Energy management of a fuel cell/ultracapacitor hybrid power system using an adaptive optimal-control method. Journal of Power Sources, 196(6): 3280 - 3289.

17. Thounthong, P., Pierfederici, S., Martin, J. P., Hinaje, M. and Davat, B. (2010). Modeling and control of fuel cell/supercapacitor hybrid source based on differential flatness control. IEEE Transactions on Vehicular Technology, 59(6): 2700 - 2710.

18. Torreglosa, J. P., Jurado, F., García P. and Fernández, L. M. (2011). Application of cascade and fuzzy logic based control in a model of a fuel-cell hybrid tramway. Engineering Applications of Artificial Intelligence, 24(1): $1-11$.

19. Fernandez, L. M., Garcia, P., Garcia, C. A., Torreglosa, J. P. and Jurado, F. (2010). Comparison of control schemes for a fuel cell hybrid tramway integrating two dc/dc converters. International Journal of Hydrogen Energy, 35(11): 5731 - 5744.

20. Payman, A., Pierfederici, S. and Meibody-Tabar, F. (2008). Energy control of supercapacitor/fuel cell hybrid power source. Energy Conversion and Management, 49(6): 1637 - 1644

21. Eren, Y., Erdinc, O., Gorgun, H., Uzunoglu, M. and Vural, B. (2009). A fuzzy logic based supervisory controller for an FC/UC hybrid vehicular power system. International Journal of Hydrogen Energy, 34(20): $8681-8694$. 
22. Erdinc, O., Vural, B., Uzunoglu, M. and Ates, Y. (2009). Modeling and analysis of an FC/UC hybrid vehicular power system using a wavelet-fuzzy logic based load sharing and control algorithm. International Journal of Hydrogen Energy, 34(12): 5223 - 5233.

23. Sakhare, A., Davari, A. and Feliachi, A. (2004). Fuzzy logic control of fuel cell for stand-alone and grid connection. Journal of Power Sources, 135(1-2): 165 - 176.

24. Ke, J., Xinbo, R., Mengxiong, Y. and Min, X. (2008). Power management for hybrid fuel cell system. IEEE in Power Electronics Specialists Conference: 504 - 509.

25. Bizon, N. (2011). Nonlinear control of fuel cell hybrid power sources: Part I - Voltage control. Applied Energy, 88(7): $2559-2573$.

26. Thanapalan, K., Fan, Z., Premier, G., Maddy, J. and Guwy, A. (2011). Control-oriented PEM fuel cell system modeling and repetitive controller design. $2^{\text {nd }}$ International Conference on Intelligent Control and Information Processing (ICICIP), 2: $1055-1060$.

27. Li, F., Li, D. \& Yang, R. (2009) A Dynamic Model of PEM Fuel Cell Stack System for Real Time Simulation. Power and Energy Engineering Conference: 1 - 5

28. Lu-Ying, C., Diong, B. and Gemmen, R.S. (2004). An improved small-signal model of the dynamic behavior of PEM fuel cells. IEEE Transactions on Industry Applications, 40(4): 970 - 977.

29. Caponetto, R., Fortuna, L. and Rizzo. A. (2005). Neural network modelling of fuel cell systems for vehicles. $10^{\text {th }}$ IEEE Conference on Emerging Technologies and Factory Automation ETFA, 1: 6.

30. Tae-Hoon, K. and Woojin, C. (2009). Control system design for the small proton exchange membrane fuel cell stack. $31^{\text {st }}$ International Telecommunications Energy Conference: 1 - 6.

31. Hou, Y., Shen, C., Yang, Z. and He, Y. (2012). A dynamic voltage model of a fuel cell stack considering the effects of hydrogen purge operation. Renewable Energy, 44: 246 - 251.

32. Chen, D., Li, W. and Peng, H. (2008). An experimental study and model validation of a membrane humidifier for PEM fuel cell humidification control. Journal of Power Sources, 180(1): 461 - 467.

33. Ye, Q., Cui, H. and Deng, M. (2010). Design of a $100 \mathrm{~W}$ fuel cell test system. Power and Energy Engineering Conference (APPEEC): 1 - 4.

34. Rosli, R. E., Majlan, E. H., Wan Daud, W. R. and Hamid, S. A. A. (2012). Hydrogen rate manipulation of proton exchange membrane fuel cell (PEMFC) stack using feedback control system. IEEE International Conference on Power and Energy (PECon): 553 - 557. 